Kohl: a Journal for Body and Gender Research

Vol. 2, No. 1 (Summer 2016)

\title{
Revisiting Community Organizing and National Liberation in the Saharawi Feminist Politics
}

Kenza Yousfi

\begin{abstract}
:
This paper examines how Saharawi feminist political praxis shapes community organizing and national liberation politics. I attempt to disrupt the binaries of national liberation and freedom through a reading of the political and temporal context of the engagements of National Union of Saharawi Women feminists in the refugee camps, in Tindouf, Algeria. From ethnographic encounters, the paper aims to challenge the linearity of violence in armed conflict by looking into nuances and politics of feminists who challenge the equation of national liberation as state-building, and simultaneously argue for more just and inclusive forms of organizing for the Saharawi community. This research looks at Saharawi feminist politics and visions for the future that are vigilantly articulated from within militarized institutions and protracted armed conflict.
\end{abstract}


We are now seeing how the ideas of "Security" and "Peace" are being completely misinterpreted and used by hegemonic powers to justify militarization and so-called "armed peace" while totally dismissing the human and women's rights perspective...In this discouraging international context, we, the activists of the World March of Women, are keeping to the path of nurturing our feminist alternatives. We continue to weave alliances with other movements that share a common vision. And we provide our ongoing support to our sisters' local struggles for a sustainable life...We will resist as many anonymous women around the world are doing everyday, from their homes and their communities, standing up for their rights and to protect other women.

We will always keep resisting.

No weapons or oppressive patriarchal power will ever keep us silent.

(Resisting Militarism, 8 March 2016, World March of Women)

On March 8, 2016, the National Union of Saharawi Women (NUSW) shared the solidarity statement released by the World March of Women, a strong ally to the NUSW and Saharawi national liberation movement. With solidarity and feminist resistance being the theme of the NUSW's annual international conference, the union amplified what the Saharawi feminists understand and work towards achieving against militarism in light of its resilience and interlinkages with armed peace and political regimes.

Saharawi feminism has strong ties to the history of the armed conflict and politics of the Saharawi national liberation movement. It is a kind of feminism that is rooted in a protracted moment of identity politics going beyond contemporary realpolitik. Saharawi feminism developed into an archetypical movement in a context of refugeeness and national liberation, and at the juncture of modern humanitarianism and law. The struggle of Saharawis, as a category, nation, and territory, has been ongoing since the late 1960s, seeking to gain international solidarity to end the protracted conflict over their land, the Western Sahara. Saharawi feminists' battle has been depicted as belonging to two performative fronts: to liberate the Western Sahara from Morocco's colonization and to advance the status of women socially, economically, and politically in the yet-to-come free nation-state of the Western Sahara (Gandolfi, 1989; Allan, 2010). From an ethnographic journey in the Saharawi refugee camps in Tindouf, Algeria, I recognize that the questions Saharawi feminists ask cannot easily be reduced to these two performative political acts. These feminists are engaging with a rather more complicated temporal and political context of community organizing that does not simply evoke gender as identity politics, but that argues for a more rigorous feminist politics of contemporary community organizing. These feminist politics seek to unlearn the equation of decolonization to the consolidation of the nation-state. Vis-à-vis state formations, Saharawi feminism helps us revisit the violence concealed within the invocation of national liberation, and offers anew their feminist visions for life projects.

The Saharawi feminist movement allows me to revisit common understandings of violence in armed conflict and in struggles for decolonization within traditional relations and militarized societies. On the one hand, writings about violence of colonialism and armed conflict have mainly been examined from gendered and 
sexual lenses that disregard other possibilities of defining complex constructions of violence in unconventional armed conflicts. It is also a moment to pose and critically reflect about the life projects that unfold before us in the contemporary moment shaped by feminist movements. On the other hand, the conversations I had with Saharawi feminists in Tindouf camps pointed to the fact that there is little to no solidarity with the Saharawi struggle from Middle Eastern and North African movements with the exception of Algeria. If politically conceptualized, solidarity could surpass the confinements of colonial and armed conflict, the two traditional constructs of solidarity networks.

\section{Gendered National Tropes in the Saharawi Warscape}

Feminist international solidarity is defined from many political standpoints. Solidarity has been key to humanitarian responses to cases of extreme violence such as armed conflict. To outline solidarity networks in the Maghreb and the Middle East, solidarity movements have been based on historical moral support to the causes that are defined by a common struggle against oppression, authoritarianism, and power structures-compare, for example, the reasons for regional support to the Palestinian struggle to the Saharawi struggle. ${ }^{1}$ Existing solidarity groups for the Palestinian struggle in forms of associations, funds, political discourses, and treaties in MENA countries are based on different historical, religious, and political reasons. As bell hooks argues, "solidarity is not the same as support. To experience solidarity, we must have a community of interests, shared beliefs and goals around which to unite, to build Sisterhood" (2015:67). Pan-Arabism strengthened solidarity, linked it to the national question of the occupied territories of Palestine, and helped build the Arab fraternity (Kazziha, 2015:28). Yet, the Western Sahara was never part of the question of pan-Arabism: the Saharawi struggle was concealed in a regional geopolitical conflict over power between rulers and nation-states; it was not a matter of decolonization.

However, with the latest ruptures in various structures of power and the rise of a different trajectory of activism and solidarity, there is a potential to rethink the possibilities that some movements bound to specific political contexts are producing on the conceptual and praxis levels. Throughout this article, the background of thought conceptualizes why it is crucial at this juncture of sociopolitics to revisit the aims of movements organized around questions of national liberation. Only through this conversation can we bring the potential of changing solidarity relations into something more than unequal paradigms of solidarity power. The potential lies in challenging the only possibility of having a donor-recipient paradigm of solidarity, what Judith Butler (1990:14-16) terms the exclusionary and coercive foundations defining the solidarity networks. With the potential of a novel political engagement with solidarity in armed conflicts, articulating the larger spectrum of questioning practices, desires, thoughts, and movements becomes possible.

\footnotetext{
${ }^{1}$ Chaba Senia, board member of the NUSW, expressed to me the indifference of Moroccan feminist groups towards the Saharawi struggle. These groups publically express their solidarity with the Palestinian national liberation struggle as it depicts the struggle against capitalism, colonialism, and imperialism. But, the Saharawi struggle also dates back to the late 1960s and is organized around similar issues of colonialism, capitalism, and self-determination. Senia states, "I understand that these feminist associations in Morocco cannot support us directly, but they can state their solidarity to us the same way they do to our Palestinian sisters" (personal interview, January 2015).
} 
It is crucial to read this development in its current geopolitical context of national liberations and revolutionary movements in North Africa and the Middle East. The visions currently being reconfigured for the MENA societies have strongly articulated new imaginaries for social and gendered justice. Not so contemporaneous, the Polisario (Popular Front for the Liberation of Saguia el-Hamra and Río de Oro, the military wing of the Saharawi Arab Democratic Republic) ${ }^{2}$ has opted for a gendered discourse to gain solidarity in the international scene. During the first few days of my stay in Bojdour camp, I heard a similar discourse among members of the National Union of Saharawi Women (NUSW). I was a Moroccan researcher who had grown up in the Gulf and lived in Egypt. NUSW members regarded themselves as different from women in these countries because, for them, they are more dignified and enjoy more rights in the Saharawi customary law.

Since the 1970s, the Saharawi camps have been advertised by journalists and scholars as feminized alongside being the most organized and politically conscious (Harrell-Bond, 1999; San Martin, 2010). Given that women were the ones who organized themselves and their children into the administrative scheme Polisario planned, this image later decrypted into the politics of solidarity networks, known as solidarios, especially from Spaniards (Harrell-Bond, 1999:145; Fiddian-Qasmiyeh, 2014:106). The focus on solidarity groups ensures that Saharawi women are emancipated, empowered, and politically represented. Saharawis in the camps reflect a modern lexicon of the humanitarian and development regimes in their institutions and legal documents.

Interlocutors holding state or institutional positions reiterate that it is a cultural norm not to subject women to violence. Asking them how they define "violence" in this case, they were surprised that it was not clear that violence meant "beating women," as the interlocutors considered it to be a common practice in the Arab region (personal interviews, January-February 2015). However, the Saharawis I encountered who weren't part of institutionalized politics used the word "beat" instead of "violence." Fiddian-Qasmiyeh argues that Polisario's official discourse on the violence-free Saharawi culture resulted in the presentation of Saharawi camps as an "ideal and unique violence-free space, unlike other generic MENA contexts and refugee camps but also unlike the West" (2014:249). Furthermore, as she notes, Saharawis identified the matter as being political, not because Saharawis did not witness instances of gender-based violence, but rather

\footnotetext{
2 The Movement for the Liberation of Sagiaut el-Hamra and Río de Oro was founded by Mohamed Sid Brahim Bassir in 1968. Bassir was a critical figure in uniting the Saharawi communities against the Spanish colonial administration. He studied in Casablanca, Cairo, and Damascus and was influenced by the socialist ideas of the Syrian Baathists (Hodges, 1984:153). Upon his return, he started recruiting members for the liberation movement to advocate for "progressive independence through negotiation with the colonial administration" (San-Martín, 2005:589). The birth of the armed resistance and Saharawi nationalism and the consolidation of the Polisario as the sole military and political representative of Saharawis came when Bassir disappeared in a peaceful demonstration in Laayoune (Zemla), where a dozen demonstrators were killed by Spanish officers. For most nationalists in Western Sahara, the Zamlah event is the first uprising that has shaped the development of the Saharawi nationalist project. Three years later, on May 10, 1973, Front Polisario was founded and its leaders started familiarizing the Saharawi population with the existence of a new front that would gather them all under one slogan: fight for freedom (Zunes \& Mundy, 2010:115).
} 
because the solidarios were willing to help only if they found the ideal refugee, woman, and political project they look for.

The neoliberal humanitarianism and its networks upon which the Saharawi camps are based have a direct impact on the ways in which these gendered identities and expectations are constructed and projected within the Saharawi refugee camps and beyond. Specific representations of Saharawi women as a homogenous category that disregards the continued practices of tribal affiliation and social class were developed and reproduced by the Polisario and non-Saharawi actors, thus reflecting specific power dynamics between Saharawi men and women. As Fiddian-Qasmiyeh shows, the contemporary representations, idealizations, and manipulations of gender and imagined gender relations in the Saharawi camps go beyond the local or national power dynamics. They are rather intertwined into the dynamics between different groups in the camps and international networks of humanitarianism. Saharawi gender relations are therefore directly implicated in, affected by, and ensuring the continuity of crucial international solidarity networks, aid networks, and power structures.

The importance of examining the reconfiguration of power structures and gendered identities, both real and imagined, lies at the heart of the temporal and political frames of the category of Saharawi. It is in this sense that I posit the armed conflict as a temporal and political frame from which to examine the Saharawi feminist movement and their attributions to the concept and actuality of violence. My aim is to explore how the Saharawi national liberation movement has pushed the feminist movement in the camps towards an articulate understanding of their politics on community organizing. This is hence a discussion on feminism and national liberation within the temporal and political frames of armed conflict and national liberation.

\section{Political and Temporal Context of the NUSW}

This article is based on an ethnography I have carried between January and February 2015 in the Saharawi refugee camps in Tindouf, Algeria. One of the questions I intended to explore was the residents' ongoing hopes for a national liberation project. Is national liberation and state formation enough to grant freedom and justice to its people? What happens when you finally gain a nation-state? Only the Saharawi women organized under the National Union of Saharawi Women (NUSW) rigorously considered these questions. Despite the radicalism of these questions, they demand a serious reflection around our contemporary politics on governance, justice, recognition, and representation. Indeed, questioning the political project of national liberation does not suggest that Saharawis would ever counter the liberation movement or its independence chants. Independence from Morocco is what legitimizes the very categories

of being Saharawis. Female and male Saharawis of all ages systematically reiterate the fact that any possibility to get organized for a cause should be done under the umbrella of Polisario (SADR Const. art II, $\S 32$ ). As an ethnographer, I wanted to go beyond this question. Capitalizing on independence is indubitably clear not only from a historical point of view, but also as a political response from a group of people who regard their sociopolitical organization as different. 
How are we to understand a political project that seeks to build a community that is not a replica of the nation-state? I argue that Saharawi feminists' engagement with the multifaceted forms of violence can build a movement focused on the question of sociopolitical community organizing. I acknowledge the contradiction posited by a movement that works from within the structure of the state and that proposes organizational models autonomous from its surveillance. In this regard, the movement is not giving up on the practicality of having a state formation in the future that could be organized more justly and inclusively. In fact, Saharawi feminists are building a political project that has the potential to articulate its own politics without falling into its own trap of being against structures. Revolutionaries and the Left-broadly definedhave struggled to envision hopeful forms of politics without using "anti," "against," "non," and "un." My question is about the political formations that emerge from the internal dynamics of the NUSW and their critique of simply resting with the goal of an independent nation-state, even as they try to work within a national liberation movement in a militarized structure. I engage with the possibilities that Saharawi feminists engender through their politics in a fraught landscape.

NUSW represents Saharawi women in the refugee camps from younger and older generations and has working groups in the Western Sahara. The NUSW is an institution created on the initiative of Polisario in 1979. Since then, it has been present in the Saharawi National Council (SNC) as one of the most important entities that emerged from the refugee camps. On account of the armed conflict pattern, women's foremost contribution is formulated in the ways in which they manage the camps. Fatma, a young member of the NUSW, recalls what her mother told her about their journey in the camps:

We [Saharawi women] were the State. We had the authority to organize, plan, and put everything into action. And they [Saharawi men] were the Army. They took care of defending us, and we took care of making life continue. (personal interview, February 2015)

This anecdote provides a comparison between structures of powers and looks at the representation of gendered subjectivities at the time of armed conflict. As I noted previously, scholars and activists who visited and produced knowledge on the camps romanticized the history of refugee camps' development. The careful modification of gender relations and political positions women occupy in the Saharawi camps' public sphere and state institutions played an important role in foreign aid attraction. For instance, Oxfam's desk-officer, Chris Mowles, describes the Saharawi society as the most equal society in terms of relationships between women and men (1984:6). Furthermore, the idea that Saharawi communities in the camps are ideal in terms of self-management and politics concealed various social struggles touching upon race and class. Up until recently, discussions on the persisting slavery of socially-considered lower class among Saharawi community were concealed, in the hope that they would not reveal the problems existing among communities in the camps. The conversations I had with Saharawi women who have witnessed the exodus and refugeeness in 1976 tell a different story. Although not with the intention of countering the official claim, Moma Sidi Abdehadi, former president of the NUSW, narrates:

Women found themselves obliged to take the lead because men were fighting on the war front. This specific moment of women finding themselves on their own can't be a victory claim for the 
revolutionary traditions of Saharawi women. When men came back to the camps after the ceasefire, a gradual return to traditional roles of women and men took place. Some women thought it was a moment of relief, to set off the burden. But for a lot of us, we were aware that the value of our roles should be brought to attention more than anytime before. It is only in the moment of proclaimed peace that we really saw that the position of women in our society will be manifested in its real scope. War conceals the structures of authority but in times of peace they are clear. We [Saharawi women in the camps] were confronted to this reconfiguration of roles... Saharawi women didn't have to fight for suffrage rights. Since the first council of the revolution, women were voting and being elected. We didn't struggle for that; the revolution gave us a lot of our vested rights. However, as long as it was given to us, we fear it will be taken away. Something you haven't struggled for, you aren't aware of its worth. For instance, we feared that we will no longer be represented in the governing bodies after the cease-fire. (personal interview, February 2015)

Administering the camps enabled an alternative understanding of the roles of women to the extent that further discourses on gender and women were framed from the vantage point of this history. To clarify how this has happened, I wish to spend more time on the historical trajectory of armed conflict-or as it will become with the cease-fire armed peace-, an important facet of the NUSW and the national liberation movement (NLM).

In the midst of armed struggle (1975-1991), Polisario had to deal with the exodus of Saharawis to Algeria. The leadership of Polisario gathered Saharawi families and survivors of Moroccan napalm bombings into groups and kept moving them into specific spatial settings. These settings have evolved throughout the forty years of the conflict to what they are now: five camps with an infrastructure of electricity, schools, and hospitals in almost every camp. Contrary to the claim that women planned the camps, Mohamed Yeslem Beisat, Polisario ambassador to Washington DC at the time of the interview, accredited the camps management and administrative planning to the Polisario leadership. Women merely found themselves in a situation where they had to help in the organization of tents and the daily management. Even when Polisario elected women to represent this "gender category" in the National Popular Congress (NPC), it was primarily to discuss the national strategy to empower women, and not to implicate them in the higher process of decision-making (Lippert, 1992: 640). In other words, Polisario wanted to make women's presence in the political apparatus of the military wing visible, but not automatically make women have their share of political power.

To further clarify this point, Polisario identified three categories of groups who represented its national strategy: women, students, and workers. The inclusion of women in the Front's strategy was inspired by other liberation movement across the world. In the preparatory documents and oral history, Polisario's male figures, especially the icon of the liberation movement El Ouali Mustafa Sayed, wrote that "equality" of women was key (ibid: 640-642). The guarantee of a successful liberation struggle and the preparation of an independent state included abolishing slavery, erasing caste differences, and dismantling tribal affiliations in an effort to transform Saharawi communities into a society that would fit the archetype of the modern nation-state (c.f. Draft document of SADR Const. Adopted by the $8^{\text {th }}$ NPC of Polisario Front in June 1991). 
Women were part of this process with no particular issue, as many of the new policies were considered advantageous. The NUSW contended that through involving more women from the NUSW in the decisionmaking, the Union would ensure its continuous presence in the military structured Council and Congress. Reflecting on the narratives of Moma Sidi Abdehadi, the development of the meaning of violence tied to the armed conflict and the silencing of alternative visions for postwar Saharawi communities unravel the ways in which violence in the Saharawi warscape is manifested. It clarifies the extent to which it can no longer be tied to normative understandings of armed conflict violence.

This history of the armed conflict and its simultaneous political developments complicate the meaning of violence. Literature on the Western Sahara depicts the war as a violent event in a temporally fragmented frame (c.f. Zunes \& Mundy 2010; San Martin 2010; Hodges 1983). I do not apply this periodization; rather, I argue that the war among Saharawis living in the camps is not seen and lived from this discontinued temporality. In fact, my engagement with the way Saharawis, specifically Saharawi women, I encountered narrate their experiences of the armed conflict starts from the larger mode that sets all these episodes together. A limited understanding of armed conflict as the battlefield would overlook the larger dynamics that shape everyday struggles and the way they have been transformed by constant violence and tropes of discourse. If armed conflict is about manufacturing and militarizing violence, then the cease-fire, understood as "armed peace," merely shifted the mode of violence as it altered the character of militarization.

Militarization in the aftermath of the cease-fire wasn't manifested in the battlefield. It was rather manifested in the way the military and its governing logics control the national liberation politics and its various fragments in the refugee camps. From this militarization trajectory, violence as a critical concept of the colonial encounter with Morocco is challenged to rethink its other modalities in the foundational concepts of the Saharawi NLM. That being said, these concepts of decolonization, militarization, and armed conflict are not concepts that break down the trajectory of the liberation movement. On the contrary, they are concepts reflected in the livelihoods of Saharawis and the interconnectedness of nation-state development, liberation, and feminist processes.

\section{A Feminist Reconceptualizing of Violence}

I locate moments of NUSW's engagement with the violence of working from within, the resilience of the militarized structure of the Polisario in these proceedings, as well as other events in the Saharawi warscape, within a conceptual framework of contested discursiveness of violence. My engagement looks at the ways in which the absences, ruptures, or transitions that characterize violence might be thought of as acts of contested discursiveness (see Hoffman, 2005:329-53). I use the term contestation and discursiveness in the sense of a movement performance. Contestation implies disagreements to a defined set of political engagement with events, concepts, and life projects. Discursiveness establishes connections, imaginations, and stories from the actions of its subjectivities. Beyond simple representation or performance, discourse implies a symbolic reconstitution of disparate elements into not so coherent and transparent plots. As I take 
up below, I employ the term contested discursiveness as a way to trouble a sense of coherence, a simple unfolding of feminist political projects. I do so also because violence challenges those subjectivities that survive in conditions of armed conflict, humanitarianism, and institutional politics. Contested discursiveness of violence offers the opportunity to explore what happens as violence both in the reflections and performances of politics of liberation.

Violence is neither a breakdown nor an evacuation of meaning. Breaking away from such a conceptualization of violence is a political challenge. In this sense, violence is not concerned with fault lines in social relations that are exacerbated by interactions. I do not wish to treat violence as if it has no content and no meaning. Though my focus here is the NUSW and its engagement with violence, the ethnographic material from which I draw is wider-ranging than the confines of the NUSW. My concern is with the way politics, narratives, and performative elements complicate violent events and their subsequent politics in a way that is not strictly coherent. The ethnographic moment-the temporal and spatial context of this fieldwork -in which I formulate my argument and observations is similarly informed. By this, I mean that I reflect on the positions - of NUSW and NLM politics_and life projects across time and location in the same way violence itself does. My aim through this formulation is to disengage with a mode of reflective linearity. Without such re-elaboration of temporalities, even the most radical political project I may adopt as an ethnographer would not permit me to understand the hopes and possibilities the Saharawi feminist movement is creating. This is an ethnographic form that neither sees moments of violence in isolation, nor construes them as exceptional.

It is further due to the praxis limitations NUSW is confronted to in regards to solidarity networks that a reconceptualization of violence is crucial. The solidarity politics in which the NUSW is involved limits discussions on the different understandings of violence within the temporal and political frames of the Saharawi NLM. It is not surprising that the politics of any feminist movement linked to a national liberation and a state-like structure mobilizes a formal discourse dictated by the international regime and the capitalist machinery of development. Nonetheless, what is more productive for feminist movements working with alternative visions for community politics is to dig deeper into the conversations and struggles that are not explicit to foreign visitors. In this way, I return to an underlying trajectory of NUSW to unmake violence as a concept and praxis, a trajectory that departs from the traditional construct of physical violence.

Deciphering the various discourses of and on violence in the Saharawi warscape first departs from the assumption that violence is solely tied to war events, to those events amplifying the enormous violent interactions happening in moments outside of war. On the other hand, it unravels the tensions to recognize the circuits of violence, how they are produced, and what their articulations are. Although any kind of political project concerned with the warscape of the Western Sahara cannot easily go beyond the colonial use of violence to govern a refugee population, another conversation with Moma Sidi Abdehadi, former president of the NUSW, touched upon the history of the NUSW, Saharawi feminist politics, intricacy of violence in the post-war period, and countering Moroccan colonial discourses. Her understanding of violence examined the in-between period of post-war and the militarization of relationships in the refugee camps. 
The older generation of Saharawi women describes the reconfiguration of gendered roles as a coup on the men's grip of institutions and power. As revolutionary as it might seem to foreigners when they visit the camps, Saharawi social understanding of gendered roles is conservative. The prison experience of Saharawi women and girls prior to the Moroccan invasion of the Western Sahara was this turning point: the existence of the NUSW and the endless provision of laws to promote women's political participation does not tell how the complexity of violence has its gendered subjective role. A caveat is however needed: the fact that one of the Saharawi positions today counter-argue armed struggle is not because of their pacifist nature. What a lot of feminists and solidarios failed to engage with is the link between independence claims, armed conflict, and a fierce refusal to militarize a community that has been partially formed by the history of war.

For example, the NOVA Western Sahara, a group of young Saharawi women against violence, advocates for peaceful means to end Moroccan colonization. However, I asked Abida Bouzid what their reaction would be if Polisario decided to go back to battlefield in the near future. She explains:

like all institutions and associations based in the Saharawi camps, NOVA Western Sahara runs under the umbrella of Polisario. I may disagree on a personal level with their decisions, but we all have to adhere and support them as Polisario represents the will of people [Saharawis]. I wish we can develop mechanisms of peaceful resistance, and this is our work at NOVA, but Polisario has done a lot throughout the forty years of refugeeness, and our people have grown tired of waiting. The war is the last hope for many, and I understand those who call for it. It will however come with a lot of loss. (personal interview, January 2015; emphasis mine).

The first generation of NUSW members feared the return of men from the battlefield to the camps. Reasons depended on different perspectives. There were women who were afraid that men would not credit the work they had done in the camps, and that they would be confined once again to the housework. Sidi Abdehadi elaborated that the Saharawi women's experience ran parallel to other international experiences, especially that of German women. The idea, as Sidi Abdehadi proposed it, was to establish a solidarity basis among all women who wanted to confront an older form of authority in their families. There is no benefit for women who are currently working in the different state-institutions in the refugee camps, because most of their work will not generate salaries for their subsistence. With such sacrifices and the precarity of work, the NUSW had to compromise by maintaining Saharawi women's right to voting, election, and representation in order to keep them active in the Saharawi political scene. Representation is not a novel problem posing critical questions on governance mechanisms on the micro or macro levels of organizing. However, representation in the case of NUSW did not mean the complete adherence to the political structure put in place after the exodus of refugees. It rather meant to carefully disengage with the politics of militarizing in governance on the levels of community organizing and state-formation. Digging deeper into the history of NUSW engages with this tapestry of disenchantment with the values of statepolitics and the desires uttered by those who are the subjects of such politics. 
The history of the NUSW was made out of the history of the war. It is what gathered all women from different class, ethnic, and social milieus into one institutional body that is not as evidently reiterating official politics of Polisario. Other than doing its official task of advocating for Saharawi independence in international forums, Saharawi women in the camps understand that they are a force of resistance against the violence of armed conflict and forced modernization of a community that aims to constitute its own model of organizing. The war had generated an everydayness of colonial violence for every Saharawi, but more so for women as Sidi Abdehadi describes: "When men left to fight, a lot of women felt that they were left behind in perpetual waiting. The hardest feeling is to await something to happen." Despite the indubitable political weight for colonization on the primary meaning of violence, NUSW older women recognized the ways in which their lifeworlds are being militarized.

\section{Nuances of the Struggle}

My stay in the refugee camps coincided with a period of intense debate on institutionalizing a draft of the family code among the Saharawi leadership, the NUSW, and activists. The two general positions were divided between those in favor of a family code governing relations between men and women, and those against having a family code to begin with. Omar Abdelsalam, the president of AFAPREDESA (La Asociación de Familiares de Presos y Desaparecidos Saharauis) explains:

just because the model of the state asks you to have laws for everything, it does not mean it will work for us [Saharawis]. If we are talking about law, we already have a law. I would rather call it our own organization of social, political, and economic issues. It is however, not written, simply because before now we did not feel the necessity to make it a sacred thing. As a community, we found solutions to social problems and justice has been the concern for us all. But justice is also political and this is why SADR feels it is time to translate it into a fixed law. This law will not speak into the way we handled our own matters. (personal interview, January 2015)

Abdelsalam believes that Saharawi women may lose entitlements they already enjoy due to the nature of this kind of social inscriptions in law. Furthermore, the discussion around the importance of law in Saharawi community cannot but touch upon the laying grounds of the Saharawi nation-state. With the armed conflict, the NLM was no longer a revolutionary movement fighting for mere decolonization. In the modern polity, a revolutionary force engaged in questions around liberation and community organizing is not able to exist in a vacuum. Abdelsalam further reiterates this point:

Saharawis weren't preoccupied with the question of the [nation-]state at first. It has become necessary only to exist within the international community. Liberation meant to Saharawis at the beginning the simple fact of living free; such they lived the entire time before the independence of neighboring countries. (personal interview, January 2015) 
This momentum shapes the politics of the Saharawi feminists who have witnessed the shift from the revolutionary claims of the national liberation movement to a more militarized council in charge of building the nation-state. Veena Das argues that the state is a form of "regulation that oscillates between a rational mode and a magical mode of being" (2004:225). The life of the state is encrypted in the signature that documents bear, denoting what she terms the "aura of legal operation," which is derived from the legality of law. That is, the "magic" of signature stems from the "unreadability of its rules and regulations," and extends to the life signature acquired in community practices (ibid). What Abdelsalam referred to in his critical formulation of Saharawi family code was in fact the documentation of the life of the state concerning its involvement in the sphere that was ordered outside its formal parameters. These parameters are set to govern and to render Saharawi political and gendered subjectivities penetrable by the bureaucratic-legal processes that are not so easily accepted by Saharawi communities despite the yearning for national liberation.

The discussion on law within developments of national liberation supposes a more complex conceptual construction. Butler's exploration of the links that bind sovereignty and governmentality as two indispensable elements of the State contributes to understanding the dynamics between state forces and activists in the Tindouf refugee camps. Although this is not a conversation on sovereignty, the eminent character of the Saharawi state (SADR) engages with what Butler calls the emerging sovereignty from within governmentality under a new form (Butler, 2004:62-64). Butler foregrounds the overlapping trajectory of the state of exception-in its national liberation movement-and the administrative and bureaucratic measures-in its executive power (ibid). This executive power also denotes administrative divisions, such as the military in the Saharawi case. And within this development of SADR's administrative and bureaucratic measures, the law as a performative act brings a configuration of "sovereignty within the filed of governmentality" (Butler, 2004:62). These two are linked in the substitution of laws as the marker of sovereignty (also to body politics) with rules as the marker of governmentality.

It is specifically this point that creates perplexities to the master plan of the national liberation movement, because all those traditional constructs of liberation, justice, violence, resistance, and conceptual frameworks from which politics operate, are not articulated from the same ground. Fatima Mehdi, the current president of the NUSW, powerfully tells me what the NUSW is preoccupied with:

We sometimes think that it is better that we still haven't gotten our independence because we have more time to work on certain issues... We are worried that with the increasing militarization of our youth, and the tough conditions of living in refugee camps, not only are we going to lose our influence in the Council, but also our impact on the community gets erased when there is an enormous support to the armed conflict. (personal interview, January 2015)

Though implicitly articulated, Mehdi argues that the nation-state building will not simply resolve the questions posed. Rather, what Saharawi feminists want to do is to experiment with the contemporary conditions to try and forge a new order that can be unmade, remade, or abandoned. Mehdi referred to working on "certain issues" among the Saharawis in the camps. These issues did not pertain to the colonial 
power. As there might or might not be a future Saharawi state, the kind of questions that will be raised will not be so different to those already being articulated. NUSW's politics are enunciated in the present conditions as being a force within a military structure whereby violence is not necessarily synonym to military occupation, but extends to the militarization of imaginaries and narratives on life and community organizing. What are the trajectories of militarizing life in the camps, and what is the conceptualization of violence uttered by the NUSW?

To answer the last question, I look at the link between the project of Saharawi NLM discourse and the politics of the Polisario. In historical accounts that tell the story of the Western Sahara, Polisario is considered the military wing of the SADR. The assumption follows the logic of a nation-state whereby the military is one part of the state constituents. However, in the Saharawi case, from its creation until today, the Polisario is the de facto governing body of all institutions, functioning not as a political wing, but as the engine that runs all life aspects. Militarization for the Saharawi feminist movement means the institutional concealment of alternative politics and the control over polities that strive to challenge the status quo by imagining a different kind of community organizing.

The main preoccupation of the Saharawi feminists is to counter a strategy of involving the military council in all proposals the NUSW is making. It is worth noting that, in spite of claims of the NUSW's political and financial independence from the Polisario, the SADR constitution-which remains temporary due to the exceptionality of war-indicates that the Polisario's National Secretariat oversees the activities of all Saharawi unions, of which the NUSW is one. The unions are the pillars of the Polisario and the evidence presented to the solidarity networks of how democratic is the SADR in the refugee camps (Es-Sweyih, 2001:62). As such, the connection of the NUSW to the Polisario as a structure and dispositive of power is not so tangible. Even when the NUSW plays an important role in attracting foreign funds to the Polisario, as Fiddian-Qasmieyh (2014: 117) shows, the solidarios were in confidence that financial contributions will not go astray if they were given to the NUSW. This doesn't as a matter of course suggest an independent voice in the Polisario Council.

The critical approach to the relationship of the NUSW to Polisario as a military structure appears to be grounded in a certain vision of community organizing and politics. This vision would have been unthinkable if the NUSW main preoccupation were to merely be liberated from a colonial Moroccan force. What is, therefore, the vision or imagination that the NUSW feminists are forging? And on which ground are the politics of NUSW feminists reshaping their communities? This seemingly simple question did not resonate with many of my interlocutors. The answers I received to these question further delineated different critical aims of national liberation, which conceptualizes the way violence is used as a lived reality in the structure of state power. In many circumstances, conversations with male position-holders differed from those of NUSW's. The imagination of the national liberation movement (Polisario as its leader), not of individuals, is to think of the governing structure, not its politics.

One could not pretend to know the answer when we are still fighting for our independence. Independence that grants our own control of the state apparatuses. Any vision for the Saharawi 
state beyond what is formulated in the SADR constitution will lose credibility because we [Saharawis] haven't talked yet about this. We are focused our national liberation, and I think that the main proposal of the Polisario Council throughout the years was to educate the population and work on the structure of the state. Its details should be dealt with once we reach that step. However, I can tell you that we are looking to build the SADR as the country-model for the Maghreb region. (65-year-old man, member of the military council)

This comparative frame of visions from institutional and movement-like standpoints doesn't suggest the existence of a binary of positions reflected on gender. In fact, women who hold high positions in Polisario or its international representative wings do not challenge the master plan of national liberation either. Senia Ahmed, a Saharawi woman who held a long diplomatic career, ponders on the imagination of liberation:

Upon the scream of all people to expel the colonizers and live free, we also wanted to gain our freedom....Algeria and Morocco got their independence, why can't we get ours? Why does Morocco want to integrate us by force? We also have the right to build our own [nation]state... because we are different. (personal interview, January 2015; emphasis mine)

There are distinct limits to a political imagination that focuses exclusively on the supposed necessities of the state and its apparatus. These limits continue to be sustained by a conception that the state is the subject of all questions and that it provides answers to the most fundamental of questions about characters and locations of politics and political life. This perspective dwells on a discourse of repetition, with a ritualized and institutionalized play of affirmations and negations that leave understandings of power negligent.

NUSW members answered my question with various tones: "There is still a lot of work to be done on the social level before independence," "I believe the model we are thinking of is the participation of all Saharawis in building their communities," "We are looking into the possibility of building a state that is inclusive of all social aspects and people. Saharawis are not all the same, and war has exacerbated these differences. Our project aims to include sociopolitical dynamics in our communities guided by our politics of freedom and equality, without blindly adopting models like most of the Maghreb countries did." These different narratives also bring up the issue of different temporalities insofar the future and the present are contested as two divergent political prospects. This tension between the aim for independence as an emancipatory moment and a national project subsumes community formation in the production of the state.

\section{Conclusion}

Saharawi feminists are faced with a political rebuttal. They are part of the liberation movement led by the military and a subversive feminist movement working on reconfiguring the dynamics of national liberation. The importance of the feminist thinking is that unlike other institutional bodies or collectives in the Saharawi refugee camps, the NUSW is pointing to the continuous building of lifeworlds. Violence exercised by the 
militarization of life domains is this refusal to admit that the Saharawi project does not end with the master plan of national independence. This in itself does not run the risk of making all lifeworlds fall into the trap of projectivism - a short-term project. It is a political praxis of its kind in that there are community struggles far more political than militarization during armed peace.

The rule of modern law as a technique of governmentality aims to solve social and political tensions by reducing them to categories, such as the family code. Saharawi feminists consider this trajectory depoliticizing: it disperses community assemblages into one mythical governance body called the state. The State is seen as more than just a political institution, but rather as an abstract principle of power and domination, inextricably linked to thought, discourse, and desire. It primarily exercises violence by transforming the confrontations of organizational forces of socialities and politics into a discursive hegemony. Unmaking the relations between an institutional body of feminists doing work from a history of war offers, perhaps, a hope for a novel feminist movement that is willing to ask the question: What are we willing to sacrifice in the name of independence?

Saharawi feminists are not so easily implicating themselves in the binary of standing with or against position. The militarization of Saharawi communities and movement is the political trajectory around which violence can be defined and understood as contested discursiveness. Despite NUSW's politics that work from the political and temporal framework of the armed conflict, and under the force of militarism, its possibilities stem from its limited groundwork and political conceptualization of the meanings of national liberation and community organizing. It also comes from its engagement with a novel feminist epistemology that is connected to the developments of the feminist activists and collectives worldwide.

The conceptualization of violence by Saharawi feminists suggests a novel engagement with the political and temporal framework of the NLM. This conceptualization looks at the forced mechanisms of governing communities from the modalities of modern polities: law, humanitarianism, development, etc. The efforts of the NUSW as this force that works from within a military structure, yet opposes militarism as a way of politics, can be read in the same way visions of community politics emanate from a feminist epistemology. This epistemology is the formation of how gendered subjectivities were formed by the NLM and the armed conflict, and were later reflected in the community and Polisario politics. The ways in which the history of the war and the humanitarian projects hegemonized the claims around the revolutionary aims of the NLM concealed efforts of Saharawi feminists to unmake national liberation as territorial independence.

In fact, my engagement with the double-edged discourses and productions of the NUSW as discursive contestation unpacks the centrality of the concept of violence to the visions, ideas, and definitions feminists have about national liberation and the future, which are distinct from militarized masculinist definitions. The possibilities forging from the Saharawi feminist politics redefine how a movement can be built amid militarizing imaginaries of community and movement politics. It is done by working on building feminist alternatives based on the reconstruction of knowledge. This type of knowledge would be able to alter understandings of violence in armed peace accompanied by militarization. 
Kohl 2.1

\section{References}

Allan, J. (2010). "Imagining Saharawi women: the question of gender in Polisario Discourse." The Journal of North African Studies, 15(2), 189-202.

Butler, J. (1990). Gender trouble: Feminism and the subversion of identity. New York: Routledge.

---. (2004). Precarious Life: The Power of mourning and violence. London: Verso.

Das, V., \& Poole, D. (2004). Anthropology in the margins of the state. School of American Research Press, NM.

Fiddian-Qasmiyeh, E. (2014). The ideal refugees: Gender, Islam and the Sahrawi politics of survival. New York: Syracuse University Press .

Gandolfi, N. (1989). "A proposito del Sahara Occidentale: testimonianze dei Canari residenti durante il periodo coloniale." Oriente moderno, VIII (LXIX), 7(12), 161-186.

Harrell-Bond, Barbara. 1999. "The experience of refugees as recipients of aid." Refugees: Perspectives on the Experience of Forced Migration. Ed. Alistair Ager. London: Pinter.

Hodges, T. (1983). Western Sahara: The roots of a desert war. Westport: L. Hill.

Hodges, T. (1984). The Western Saharans. London: Minority Rights Group.

Hoffman. D. (2005). "Violent events as narrative blocs: The disarmament at Bo, Sierra Leone." Anthropological Quarterly, 78(2): 329-353.

Hooks, B. (2015). Feminist theory: from margin to center. London: Routledge.

Kizziah, W. (2015). Palestine in the Arab dilemma. New York: Routledge.

Lippert, A. (1992). "Sahrawi women in the liberation struggle of the Sahrawi people." Signs, 17(3), 636-651.

San Martín, P. (2010). Western Sahara: The refugee nation. Cardiff: University of Wales Press.

Mowles, C. (1986). "Desk officer's report on trip to the Sahrawi refugee camps near Tindouf, Southern Algeria, June 16-21, 1986." Oxfam. Refugee Studies Centre Grey Literature Collection, University of Oxford.

Zunes, S., \& Mundy, J. (2010). Western Sahara: War, nationalism, and conflict irresolution. Syracuse: Syracuse University Press. 